\title{
Concise syntheses of GB22, GB13 and himgaline by cross-coupling and complete reduction
}

\author{
Eleanor M. Landwehr, ${ }^{\star}$ Meghan A. Baker, ${ }^{\ddagger}$ Takuya Oguma ${ }^{\ddagger}$ Hannah E. Burdge, Takahiro Kawajiri, \\ Ryan A. Shenvi*
}

Department of Chemistry, The Scripps Research Institute, 10550 North Torrey Pines Road, La Jolla, California 92037 , United States

\begin{abstract}
Class III neuroactive metabolites from the bark of Galbulimima belgraveana occur in variable distribution and are not easily procured by chemical synthesis. Here we decrease the synthetic burden of himgaline to nearly one-third of the prior best (7-9 vs. 19-31 steps) by cross-coupling high fraction aromatic $\left(\mathrm{F}_{\mathrm{Ar}}\right)$ building blocks followed by complete, stereoselective reduction to high-fraction $\mathrm{sp} 3\left(\mathrm{~F}_{\mathrm{sp}} 3\right)$ products. This short entry into GB alkaloid space allows its extensive exploration and biological interrogation.
\end{abstract}

Extracts from Galbulimima belgraveana and baccata have yielded related neuroactive alkaloids classified by connectivity between piperidine and decalin domains (Galbulimima alkaloids, classes I - IV, Figure 1a). ${ }^{1}$ The simplest, class I GB alkaloid, himbacine (15 mcbits/atom), ${ }^{2}$ was found to antagonize muscarinic receptors M1-5 (rhodopsin-like GPCRs, subfamily $\mathrm{A} 18)^{3,4}$ and its enantiomeric series was developed into Vorapaxar, an antagonist of related GPCR PAR-1 (subfamily A15). ${ }^{5}$ Classes II-IV have not been well-developed towards biological goals, ${ }^{6}$ but unpredictable bark content ${ }^{7}$ and potential for development ${ }^{8}$ have attracted significant interest from the synthetic community. ${ }^{9-14}$ GB alkaloid classes II and III have proved especially challenging to access (18-33 steps), although pioneering solutions have appeared (see SI for a full outline of each). ${ }^{9-}$ ${ }^{14}$ The most concise syntheses by Movassaghi, ${ }^{10}$ Sarpong ${ }^{13}$ and $\mathrm{Ma}^{14}$ obtained GB13 in 18-19 steps, and generated crucial data to aid our exploration. In search of a general strategy to access GB alkaloid chemical space, we targeted GB22 (3, Figure 1b), a low-abundance class III alkaloid (1.8 ppm, milled bark) whose aromatic ring might allow rapid entry and diversification to complex congeners. ${ }^{15}$ In this design, high fraction aromatic $\left(\mathrm{F}_{\mathrm{Ar}}\right)$ intermediate 5 containing $15 \mathrm{sp}^{2}$ atoms (11 mcbits/atom) might be reduced ${ }^{13,16}$ to generate the 11 tetrahedral stereocenters in the complex alkaloid himgaline (1,21 mcbits/atom). This is a classical strategy, represented by the earliest alkaloid synthesis - coniine in 1886 - in which reduction converted a simple aromatic to a high $\mathrm{F}_{\mathrm{sp}} 3$ alkaloid, albeit with one stereocenter whose stereochemistry was not controlled. ${ }^{17}$

Success in himgaline would require relay of stereochemical configuration from the single stereocenter of 5 to nine prochiral carbons, including the concave-facing methine $\mathrm{C}-\mathrm{H}$ bonds of GB13 (2). Although these hydrogens might epimerize to the concave face, the potential instability of extended enols and the existence of other low-energy configurations at ring junctions complicated our analysis of stereochemical equilibration (e.g. 9,10,15-epi-GB13 and 15-epi-GB13 are $2.6 \mathrm{kcal} / \mathrm{mol}$ and $1.3 \mathrm{kcal} / \mathrm{mol}$ lower in energy than GB13; see SI). Here we report unusually concise syntheses of GB22, GB13 and himgaline using an endo-selective attached-ring cross-coupling and arene reduction that significantly reduce the synthetic burden compared to prior art.

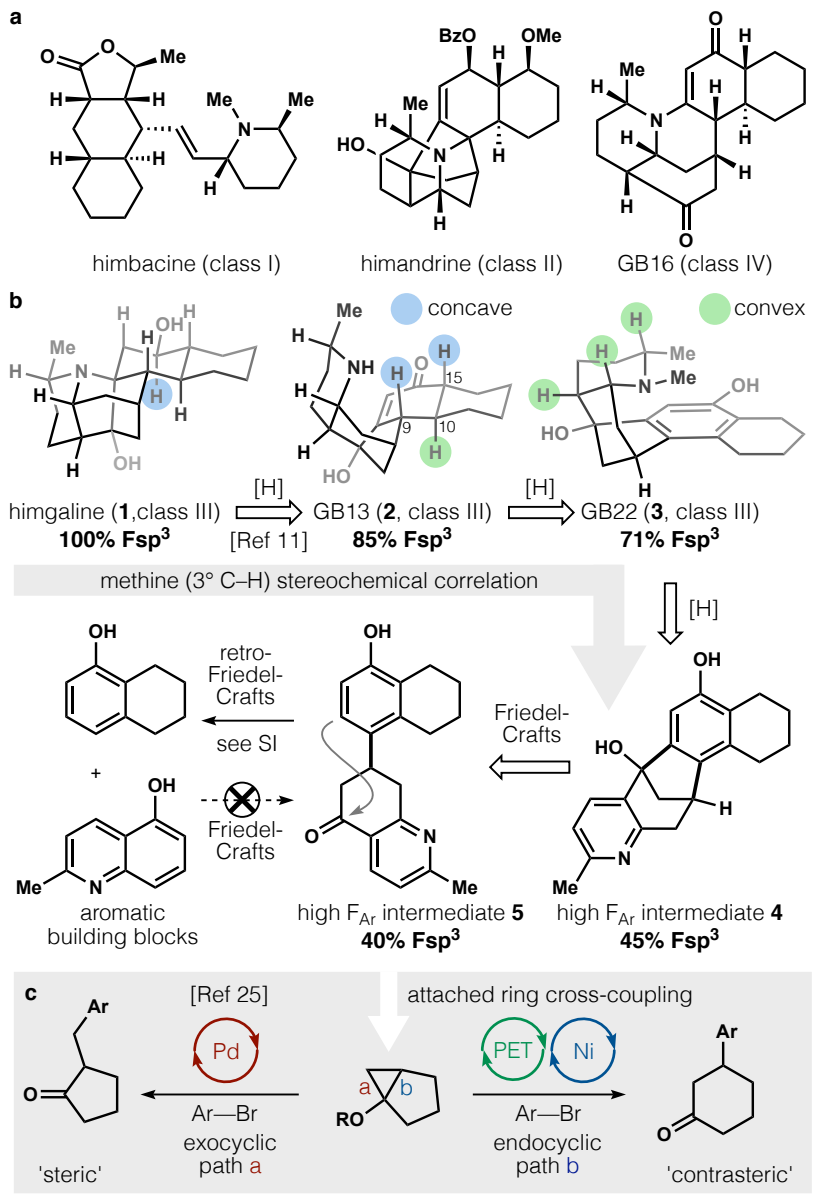

Figure 1. Representative Galbulimima (GB) alkaloids and synthetic analysis. a. Chemical space related to GB alkaloids. b. Through-class retrosynthetic analysis relating GB alkaloids. c. A high $\mathrm{F}_{\mathrm{Ar}}$, low $\mathrm{F}_{\mathrm{sp}} 3$ intermediate undergoes rapid attached ring scission, but can be formed under mild cross-coupling conditions. 
Retrosynthetic analysis of GB22 (Figure 1b) identified an embedded attached-ring system, which could be unmasked by pyridine hydrogenation ${ }^{13}$ and intramolecular ketone arylation transforms. Despite the simplicity of 5, the most obvious disconnection - enone conjugate addition - fails. A direct FriedelCrafts addition of $\mathbf{4}$ into the cyclohexadienone conjugate acid of $\mathbf{3}$ (Figure $2 a)^{18}$ is prevented by preferential protonation of $\mathbf{4}$ and decomposition of $\mathbf{5}$ mediated by acids (see below). We thought that if the oxocarbenium ion were replaced with a $\beta$ keto carbon-centered radical, we might circumvent the FriedelCrafts by interception of an arylnickel complex (Figure 2c). ${ }^{19}$ $\beta$-Keto radical formation has been implicated in the ring-opening of siloxycyclopropanes by photoinduced electron transfer (PET) to 1,4-dicyanonaphthalene (DCN). ${ }^{20}$ Inspired by the recent success of photoredox/Ni dual catalytic cross-coupling platforms,${ }^{21}$ we considered a system in which a photoexcited catalyst might oxidatively cleave a siloxycyclopropane with endo-selectivity, ${ }^{22,23,24}$ leading to arylnickel capture and reductive elimination. Typically, transition-metal catalyzed arylations of cyclopropanols and siloxycyclopropanols favor cleavage of the least hindered cyclopropane bond (path a, Figure 1c). ${ }^{25}$ In contrast, this electron transfer arylation would provide the opposite regioselectivity (path b).

a

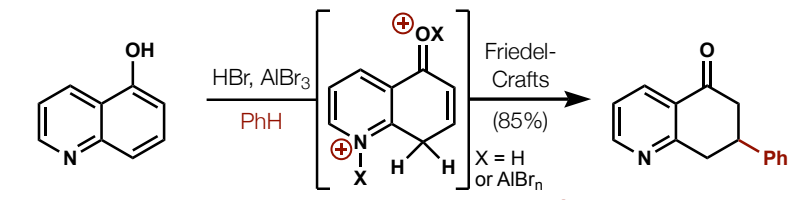<smiles>COc1ccc2c(O)cccc2n1</smiles>

3

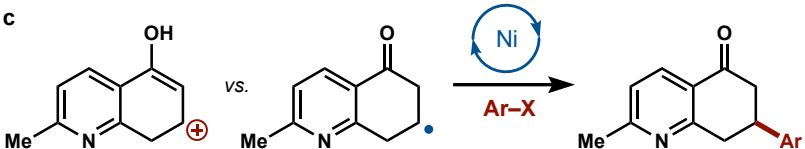

Figure 2. The failure of a Friedel-Crafts conjugate arylation leads to the development of the corresponding radical cross-coupling.

Early efforts to develop a dual catalytic endo-selective siloxycyclopropane arylation identified the Doyle-MacMillan dual catalyst system of $\left[\operatorname{Ir}\left\{\mathrm{dF}\left(\mathrm{CF}_{3}\right) \text { ppy }\right\}_{2}(\mathrm{dtbbpy})\right] \mathrm{PF}_{6}$ and $\mathrm{Ni}($ dtbbpy $) \mathrm{Cl}_{2}$ as a good starting point (see Figure 3$) .{ }^{26}$ Yields of coupled product 6 proved dependent on heat removal by air circulation and difficult to reproduce without tight control of temperature (B-D, Figure 3, were major byproducts). Ultimately, the reaction setup was altered to accommodate the use of a water bath for temperature control and heating. In combination with organic dyes like $3 \mathrm{CzClIPN}$ and $4 \mathrm{CzIPN}$, the reaction proved more reliable and offered shorter reaction times, lower costs and more flexibility over conditions. ${ }^{27}$ Highly-polar solvents such as DMA and DMF were competent in this chemistry, but DMSO out-performed both. Additionally, carbonate bases were ineffective and phosphate bases proved inferior and less consistent than organic pyridine bases like 2,6-lutidine and 2 -picoline. The yield of $\mathbf{6}$ decreased when we employed photocatalysts that had higher or lower oxidation potentials than $3 \mathrm{CzClIPN}$. Finally, the reaction did not proceed in control reactions that excluded each of the reagents. These conditions were generally successful across a variety of siloxycyclopropanes and haloarenes. In all cases, the retrosynthetic disconnections using a conjugate addition transform would lead to a cyclohexadienone that exists as the phenol tautomer (B).
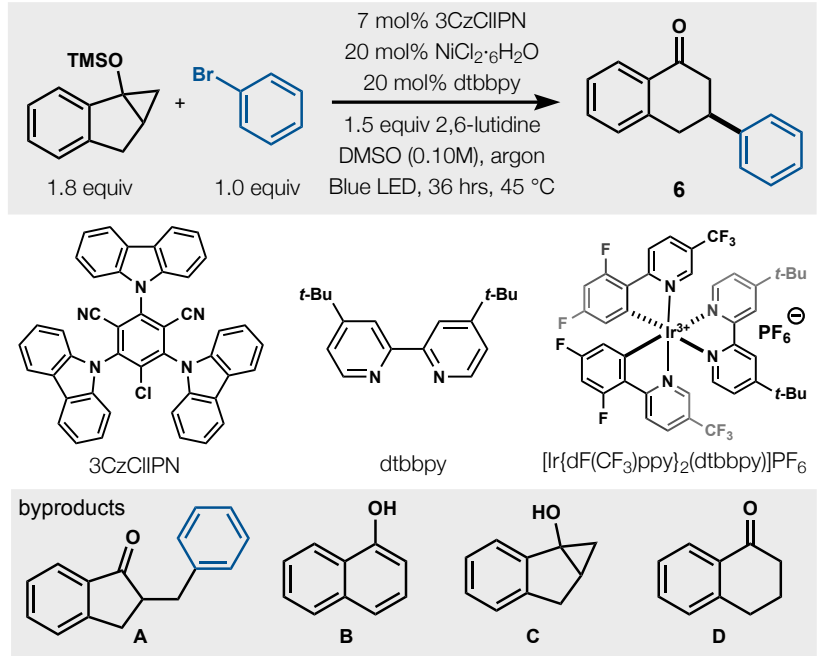

\begin{tabular}{|c|c|c|}
\hline Entry ${ }^{a}$ & Deviation & Yield of $6(\%)^{b}$ \\
\hline 1 & none & $73(21)^{c}$ \\
\hline 2 & [Ir] (1 ${ }^{\text {st }}$ generation) [Ref 22] $]^{\mathrm{e}}$ & $25-78$ \\
\hline 3 & 1.8 equivalents bromobenzene & 69 \\
\hline $4^{d}$ & {$[\mathrm{lr}]$ not $3 \mathrm{CzC} \| \mathrm{PN}, 35^{\circ} \mathrm{C}$} & $58(15)^{c}$ \\
\hline 5 & OTES, not OTMSe & 10 \\
\hline 6 & 2-picoline & 60 \\
\hline 7 & $\mathrm{KH}_{2} \mathrm{PO}_{4}$ & 35 \\
\hline 8 & 4CzIPN not 3CzCIIPN & 64 \\
\hline 9 & without $3 \mathrm{CzCIIPN}$ & C \\
\hline 10 & no base & $<5$ \\
\hline 11 & no dtbbpy & 0 \\
\hline
\end{tabular}

Figure 3. Variation from optimal conditions. ${ }^{a} 0.1 \mathrm{mmol}$ bromobenzene, ${ }^{b 1} \mathrm{H}$ NMR yield, ${ }^{c}(\%$ yield of $\mathbf{A}),{ }^{d} 0.25 \mathrm{mmol}$ bromobenzene. ${ }^{e}$ with [Ir].

Neither electron-withdrawing nor electron-donating groups on the arene effected the efficiency of coupling and heterocycles coupled with efficiency (oxidant-sensitive arenes were problematic, however; see SI). The reaction translated from bromoarenes to 1-bromocyclohexene, albeit in reduced yield. Encouraged by the scope of this cross-coupling, especially with regard to heterocyclic substrates, we investigated entry into the synthesis of GB22 (Scheme 1). Ketone 7 is listed commercially and can be prepared in one step by condensation of 1,3-cyclopentanedione, methyl vinyl ketone, and ammonia. ${ }^{28}$ Conversion to siloxycyclopropane $\mathbf{8}$ was carried out via silyl enol ether formation, followed by Simmons-Smith cyclopropanation using the Shi modification. ${ }^{29}$ An alternative 3-step route to 8 from methyl 2-chloro-6-methyl-nicotinate was also developed to avoid the difficult purifications of the Simmons-Smith route. Cross-coupling with bromoarene $9 \mathbf{a}$ or $\mathbf{9 b}$ (2 steps from 1-naphthol) ${ }^{30}$ occurred cleanly, after optimization to account for ortho-substitution that leads to steric crowding of the intermediate arylnickel. The higher yield of anisole $\mathbf{9 b}$ likely reflects the low bond dissociation enthalpy of $\mathrm{C}-\mathrm{H}$ bonds in benzyl ether $9 \mathbf{a}$. 

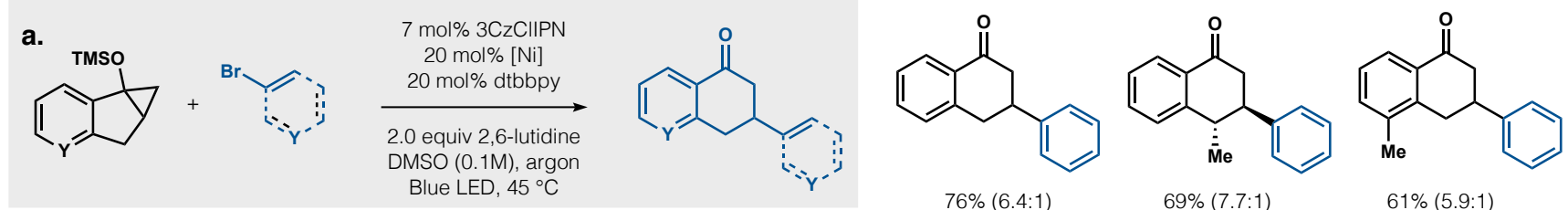

<smiles>COc1ccc2c(c1)C(=O)CC(c1ccccc1)C2</smiles><smiles>[R]c1ccc(C2CC(=O)c3ccccc3C2)cc1</smiles>

$69 \%(7.7: 1)$

$61 \%(5.9: 1)$<smiles>O=C1CC(C2=CCCCC2)Cc2ccccc21</smiles><smiles>COc1ccc(C2CC(=O)c3ccccc3C2)c2c1CCCC2</smiles>

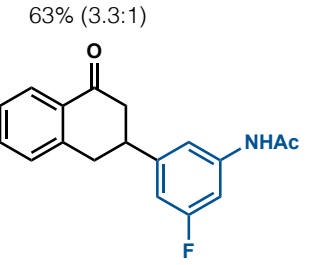

$$
\begin{aligned}
& \mathbf{R}=\mathrm{CF}_{3} \\
& \mathbf{R}=\mathrm{Cl} \\
& \mathbf{R}=\mathrm{t}-\mathrm{Bu} \\
& \mathbf{R}=\mathrm{Ph} \\
& \mathbf{R}=\left(\mathrm{CH}_{2}\right)_{2} \mathrm{OH}
\end{aligned}
$$

$71 \%(6.7: 1.0)$ $70 \%(5.0: 1.0)$ $72 \%(5.0: 1.0)$ $75 \%(5.0: 1.0)$ $89 \%(5.0: 1.0)$<smiles>O=C1CC(c2ccc(F)cn2)c2ccccc21</smiles>

$49 \%(>20: 1)$<smiles>Nc1ccc(C2CC(=O)c3ccccc3C2)cc1F</smiles>

$34 \%(6.7: 1)$

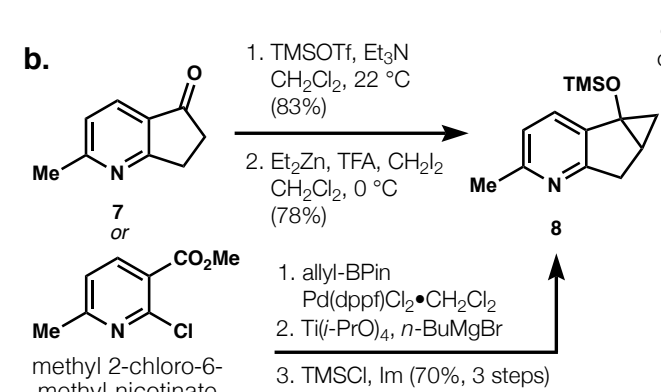

9 mol\% 3CzCIIPN (9a) or $7 \mathrm{~mol} \% 4 \mathrm{CzIPN}(\mathbf{9 b})$

b.

3. TMSCI, Im (70\%, 3 steps)

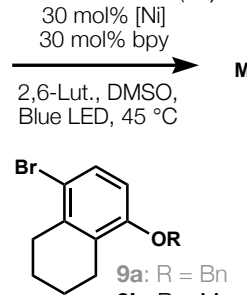<smiles>[R]Oc1ccc(C2CC(=O)c3ccc(C)nc3C2)c2c1CCCC2</smiles>



10a: $R=B n\left(37^{1} H\right.$ NMR\%;

$33 \%$ isolated)

10b: $R=\operatorname{Me}\left(64 \%{ }^{1} \mathrm{H}\right.$ NMR; 9b: $R=M e$ (57\% isolated)
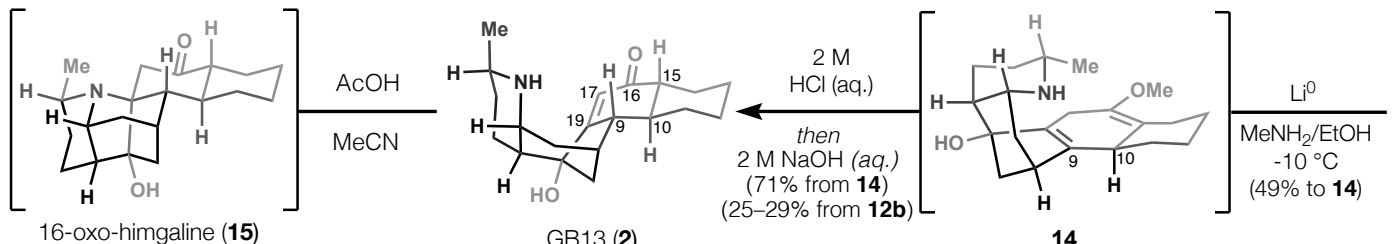

$(53 \%) \downarrow \mathrm{NaBH}(\mathrm{OAc})_{3}$

GB13 (2)

[6-8 steps]

vs.

[18-31 steps, Ref 9-14]

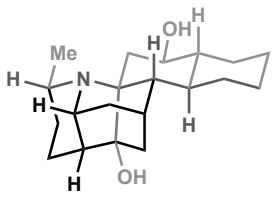

himgaline (1)

[7-9 steps vs. 19-32]

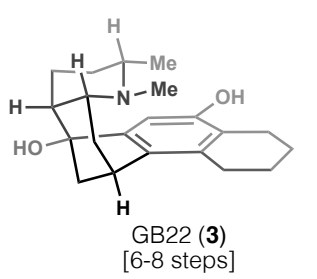

14

[X-ray in SI]

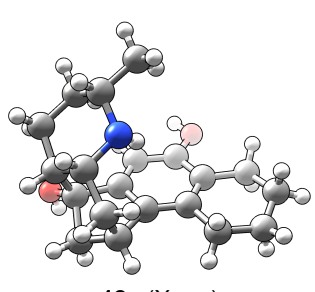

12a (X-ray)

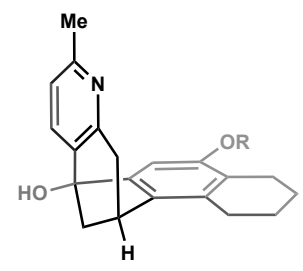

4: $R=H(52 \%)$

11: $R=\operatorname{Me}(86 \%)$


12a: $R=H(81 \%)$

12b: $R=\operatorname{Me}(95 \%)$

\begin{tabular}{c|l}
$\mathrm{BBr}_{3}, \mathrm{CH}_{2} \mathrm{Cl}_{2}$ & $(75 \%$ \\
0 to $22{ }^{\circ} \mathrm{C}$ & from
\end{tabular}

0 to $22^{\circ} \mathrm{C} \downarrow$ from $\mathbf{1 2 b}$ )

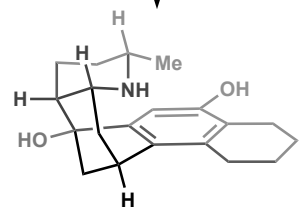

$12 \mathrm{a}$

Figure 4. Scope and application. a. Endo-selective $\mathrm{sp}^{3}-\mathrm{sp}^{2}$ cross-coupling: \% isolated yield (endo:exo). b. A short synthesis of GB22, GB13 and himgaline via iterative, stereoselective reduction of multiple correlated carbons.

The high $\mathrm{F}_{\mathrm{Ar}}$ attached-ring intermediates $\mathbf{1 0 a} / \mathbf{b}$ incorporated all the skeletal carbons of GB22, GB13 and himgaline, but the projected Friedel-Crafts arylation proved difficult. First, as suggested by positive Hammett parameters, ${ }^{31}$ dominant inductive effects disfavor attack by the meta-position of the phenolic ether. Koltunov found benzene itself to cyclize efficiently with 5-quinolol using triflic acid $\left(\mathrm{F}_{3} \mathrm{CSO}_{3} \mathrm{H}\right),{ }^{18}$ but initial screens of strong Brønsted acids in our system delivered only small quantities of 4 . Triflic acid instead competitively protonated $10 \mathbf{a} / \mathbf{b}$ and effected a retro-Friedel-Crafts arylation to cleave the hard- won $\mathrm{C}-\mathrm{C}$ bond and return quinolol 3 (see Figure 1 and SI). Typical Lewis acids like $\mathrm{AlCl}_{3}$ also did not yield 11 (see SI for a table of conditions). However, when inorganic aluminum Lewis acids were mixed with hexafluoroisopropanol (HFIP), tetracycle 4 was finally observed, albeit in low yield, along with $\mathbf{3}$. We suspect that an aluminum species such as $\mathrm{Al}\left[\mathrm{OCH}\left(\mathrm{CF}_{3}\right)_{2}\right]_{\mathrm{n}} \mathrm{Cl}_{\mathrm{m}}$ might act as an efficient Lewis acid ${ }^{32}$ or hydrogen-bonding catalyst. Minimization of strong Brønsted acidity (i.e. $\mathrm{HCl}$ liberation) was accomplished by adding diethylaluminium chloride to HFIP, which quickly and exothermically evolved gas (likely 
ethane) to generate a new complex, tentatively assigned as $\mathrm{Al}\left[\mathrm{OCH}\left(\mathrm{CF}_{3}\right)_{2}\right]_{2} \mathrm{Cl}$ and its aggregates. The mechanism of cyclization may involve acidification of HFIP, formation of a strong double hydrogen-bond donor bridged by aluminum, or formation of a strongly Lewis acidic complex. ${ }^{33}$ HFIP alone ${ }^{34}$ did not promote any reaction of 2 . This procedure led to clean and reproducible cyclization of the acid-labile attached ring as either the parent phenol $4(52 \%)$ or its methyl ether $11(86 \%)$, depending on use of 10a (to 4) or 10b (to 11).

Both 4 and 11 could be hydrogenated over $\mathrm{Rh} / \mathrm{Al}_{2} \mathrm{O}_{3}$ with exquisite stereocontrol to $\mathbf{1 2} \mathbf{a} / \mathbf{b}$ (other diastereomers not detected), by analogy to related work on GB13 wherein a larger, pre-saturated decalin motif provided steric shielding. ${ }^{13}$ Here, the benzene nucleus was unaffected by rhodium-catalyzed hydrogenation, but despite its planarity, small size and ability to adsorb to metal surfaces, ${ }^{35}$ it efficiently blocked the concave face of the pyridine ring. Whereas $\mathbf{1 2 a}$ could be $N$-methylated $\left(\mathrm{CH}_{2} \mathrm{O}\right.$ (aq.), $\left.\mathrm{NaCNBH}_{3}\right)$ to $\mathrm{GB} 22$ directly, 12b required demethylation by $\mathrm{BBr}_{3}(75 \%)$, resulting in one more operation than the benzyl ether series, but almost double the yield $(16 \%$ vs. $29 \%, 3$ vs. 4 steps). ${ }^{1} \mathrm{H}$ - and ${ }^{13} \mathrm{C}$-NMR spectra of synthetic GB22 were identical to those reported by Lan and Mander (see SI). ${ }^{15}$

The next arene reduction benefited from retention of the methyl ether in 12b and probed the role of the piperidine ring in control of stereochemistry at the incipient decalone. Birch reduction $\left(\mathrm{Li}^{0}\right.$ or $\mathrm{Na}^{0}$ in $\left.\mathrm{NH}_{3}(\mathrm{l})\right)$ and electrochemical reduction proved unsuccessful, but Benkeser reduction ${ }^{36}\left(\mathrm{Li}^{0}\right.$ in $\mathrm{MeNH}_{2}$, $\mathrm{THF} / i-\mathrm{PrOH})$ was unique to effect clean reduction of the anisole. Proton source and metal proved crucial: $\mathrm{MeOH}, \mathrm{EtOH}$ and $t$-BuOH did not promote reduction, and neither was $\mathrm{Na}^{0}$ effective. The recently reported Koide reduction ${ }^{37}\left(\mathrm{Li}^{0}\right.$, ethylenediamine, THF) worked extremely well and yielded similar amounts of product to $\mathrm{Li}^{0} / \mathrm{MeNH}_{2}$ with greater operational ease (see SI). A single diastereomer and regioisomer predominated (14, for X-ray structure see SI), resulting from intermolecular protonation of $\mathrm{C} 10$ from the convex face, despite the potential for intramolecular proton transfer to $\mathrm{C} 9$ from the piperidine $\mathrm{N}-$ $\mathrm{H}$, modeled only $2.46 \AA$ apart in 12a (X-ray). Minor byproduct pathways included demethylation (to $\mathbf{1 2 a}$ ), over-reduction of the arene and $c a .10 \%$ of a regioisomer. Hydrolysis of 14 with $2 \mathrm{M}$ aqueous $\mathrm{HCl}$, followed by basification ( $4 \mathrm{M} \mathrm{NaOH})$ led to GB13 in 71\% yield, with each of the remaining methine stereocenters adopting the desired configuration. Only a single methine $(\mathrm{C} 10)$ positioned its hydrogen to the convex face, whereas two new stereocenters $(\mathrm{C} 9, \mathrm{C} 15)$ derived from prochiral, planar carbons that projected hydrogens inward. This stereochemistry may reflect, in part, the thermodynamic preferences of ring-tautomer (aza-Michael product) 16-oxo-himgaline (15), which forms spontaneously under acidic conditions. ${ }^{11}$ Whereas the decalin cis-ring fusion of GB13 is calculated to be more stable by $1.3 \mathrm{kcal} / \mathrm{mol}$, the trans-ring fusion of 16-oxo-himgaline is lower in energy by $2.7 \mathrm{kcal} / \mathrm{mol}$ (see SI). We speculate that the piperidine ammonium may deliver a proton internally to the enone $\gamma$ carbon C9 since $\beta, \gamma$ to $\alpha, \beta$-enone isomerization occurs under acidic conditions and an extended enol tautomer is occluded on its concave face by this ammonium (see $14 \mathrm{X}$-ray, SI). The final stereogenic methine $\mathrm{C}-\mathrm{H}$ was installed according to a one-step protocol, as first demonstrated in a 33-step synthesis of himgaline. ${ }^{12}$ Thus, 9 prochiral carbons of high $\mathrm{F}_{\text {Ar }}$ intermediate $\mathbf{1 0 b}$ was converted in 3 steps to 9 new stereocenters ( 8 carbon, 1 nitrogen) by relay of increasing stereochemical information through simple reductions. To access pure GB13, 14 can be chromatographed to remove reduction byproducts prior to acid hydrolysis, but this is unnecessary for conversion to pure himgaline, resulting in a 7-9 step synthesis, depending on isolation of 14 and designation of official starting material ( $7 v s$. cyclopentane-1,3-dione vs. methyl 2-chloro-6-methyl-nicotinate, see SI and Figure 5).

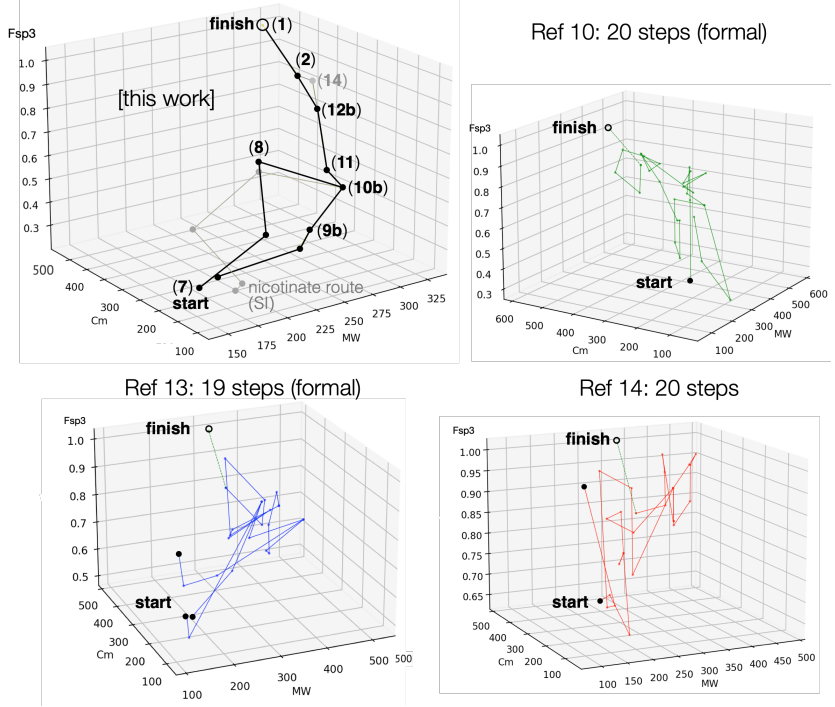

Figure 5. Himgaline syntheses as walks through a chemical space parameterized by $\mathrm{F}_{\mathrm{sp}} 3\left(\#_{\mathrm{sp}} 3 / \mathrm{C}_{\text {total }}\right), \mathrm{C}_{\mathrm{m}}$ (mcbit) and molecular weight $(\mathrm{Da})$.

Himgaline is constitutionally related to cross-coupled product $\mathbf{1 0 b}$ by these iterative additions of $\mathrm{H}_{2}$, excluding the $O$ methyl embedded in starting material $9 b$. Since hydrogen atoms are typically omitted from complexity calculations, ${ }^{38}$ the progression of high $\mathrm{F}_{\mathrm{Ar}}$ intermediates to $100 \% \mathrm{~F}_{\mathrm{sp}} 3$ (himgaline) is exclusively due to information carried by molecular topology (C-C, C-N, C-O bonds) and chirality content. Here, the 260.16 mcbits $^{2}$ of des-methyl 10b increase to 477.83 over 5 steps, or 43.5 mcbits per step. Visualized as a walk through chemical space $^{39}$ (Figure 5), the synthesis begins proximal to commercial space (low molecular weight, low complexity and low $\mathrm{F}_{\mathrm{sp}} 3$ /high $\mathrm{F}_{\mathrm{Ar}}$ ), converges early by cross-coupling and then rapidly reaches the high complexity, weight and $\mathrm{F}_{\mathrm{sp}} 3$ of himgaline, typical of remote GB alkaloid space. In contrast, the shortest prior synthesis of himgaline (formal, racemic, 19 steps) varies 148.45 mcbits over 15 steps ( 9.9 mcbits per step) from the latest point of convergency. Each route allows its own unique exploration of different areas of chemical space. However, recognition that the key methine $\mathrm{C}-\mathrm{H}$ stereocenters can be stereoselectively appended from prochiral $\mathrm{sp}^{2}$ carbons of an aromatic himgaline core simplifies access to GB alkaloid space in a clear and quantifiable way. Whereas this analysis focuses on navigation to high complexity chemotypes, we anticipate that GB structural chemical space can be better parameterized to relate to the biological targets and relative potencies among family members. Given the structural similarity among the 25 Class II and III congeners, this approach is likely to prove general and finally provide a means to deconvolute the targets, functions and translational potential of the GB alkaloids. 


\section{ACKNOWLEDGEMENTS}

We thank Leo Smith (Concordia College, Moorhead) for assistance with the synthesis of $\mathbf{8}$ and Sarah Jane Hill for assistance with Matplotlib. We thank Professor Nathan Jui for sending 3Dprinted racks for photochemical reactions and Cheng Bi for help with high pressure hydrogenation. We thank Professor Hans Renata and Dr. Steven Crossley for proofreading. Arnie Rheingold, Milan Gembicky and Erika Samolova are acknowledged for X-ray crystallographic analysis. Support was provided by the National Institutes of Health (R35 GM122606), the National Science Foundation (CHE 1856747), the Skaggs Graduate School (fellowship to E.M.L.), Bristol Myers Squibb (fellowship to M.A.B.), Jiangsu Industrial Technology Research Institute (JITRI) (support for M.A.B. and H.E.B.), Shionogi \& Co., Ltd. (support for T.O.) and the Japan Society for the Promotion of Science (JSPS, Number: 17J08551 for T.K.).

(1) Rinner, U. Galbulimima alkaloids. Alkaloids. Chem. Biol. 2017, 78, 109-166.

(2) Böttcher, T. An Additive Definition of Molecular Complexity. J. Chem. Inf. Model. 2016, 56, 462-470.

(3) Gilani, A. H.; Cobbin, L. B. Interaction of himbacine with carbachol at muscarinic receptors of heart and smooth muscle. Arch. Int. Pharmacodyn. Ther. 1987, 290, 46-53.

(4) Miller, J. H.; Aagaard, P. J.; Gibson, V. A.; McKinney, M. Binding and Functional Selectivity of Himbacine for Cloned and Neuronal Muscarinic Receptors. J. Pharmacol. Exp. Ther. 1992, 263, 663-667.

(5) Chackalamannil, S.; Wang, Y.; Greenlee, W. J.; Hu, Z.; Xia, Y.; Ahn, H. S.; Boykow, G.; Hsieh, Y.; Palamanda, J.; Agans-Fantuzzi, J.; Kurowski, S.; Graziano, M.; Chintala, M. Discovery of a Novel, Orally Active Himbacine-Based Thrombin Receptor Antagonist (SCH 530348) with Potent Antiplatelet Activity. J. Med. Chem. 2008, 51, 3061-3064.

(6) Collins, D. J.; Culvenor, C. C. J.; Lamberton, J. A.; Loder, J.W.; Price, J.R. 1990. Plants for Medicines. Melbourne, Australia; Commonwealth Scientific and Industrial Research Organization (CSIRO), pg. 105.

(7) Binns, S.; Dunstan, P. J.; Guise, G. B.; Holder, G. M.; Hollis, A. F.; McCredie, R. S; Pinhey, J. T.; Prager, R. H.; Rasmussen, M.; Ritchie, E.; Taylor, W. C. The Chemical Constituents of Galbulimima species. Aust. J. Chem. 1965, 18, 569-573.

(8) Thomas, B. Psychoactive plant use in Papua New Guinea: a review. Science in New Guinea, 2000, 25, 33-59.

(9) Mander, L. N.; McLachlan, M. M. The Total Synthesis of the Galbulimima Alkaloid GB 13. J. Am. Chem. Soc. 2003, 125, 24002401.

(10) Movassaghi, M.; Hunt, D. K.; Tjandra, M. Total Synthesis and Absolute Stereochemical Assignment of (+)- and (-)-Galbulimima Alkaloid 13. J. Am. Chem. Soc. 2006, 128, 8126-8127.

(11) Shah, U.; Chackalamannil, S.; Ganguly, A. K.; Chelliah, M.; Kolotuchin, S.; Buevich, A.; McPhail, A. Total Synthesis of (-)-Himgaline J. Am. Chem. Soc. 2006, 128, 12654-12655.

(12) Evans, D. A.; Adams, D. J. Total Synthesis of (+)-Galbulimima Alkaloid 13 and (+)-Himgaline. J. Am. Chem. Soc. 2007, 129, 1048-1049.

(13) Larson, K. K.; Sarpong, R. Total Synthesis of Alkaloid ( \pm )G.B. 13 Using a Rh(I)-Catalyzed Ketone Hydroarylation and Late-

\section{Supporting Information}

The Supporting Information is available free of charge on the ACS Publications website.

Experimental procedures, copies of NMR spectra, X-ray structure reports, full outlines of prior syntheses, coordinates and Matplotlib Python code.

\section{AUTHOR INFORMATION}

\section{Corresponding Author}

*rshenvi@scripps.edu

Notes

The authors declare no competing financial interest.

¥These authors contributed equally.

Competing Interests: A provisional patent has been filed.

\section{REFERENCES}

Stage Pyridine Reduction J. Am. Chem. Soc. 2009, 131, 13244 13245.

(14) Zi, W.; Yu, S.; Ma, D. A Convergent Route to the Galbulimima Alkaloids (-)-GB 13 and (+)-GB 16. Angew. Chem. Int. Ed. 2010, 49, 5887-5890.

(15) Lang, P.; Herlt, A. C.; Willis, A. C.; Taylor, W. C.; Mander, L. N. Structures of New Alkaloids from Rain Forest Trees Galbulimima belgraveana and Galbulimima baccata in Papua New Guinea, Indonesia, and Northern Australia. ACS Omega 2018, 3, 1912-1921.

(16) Welin, E. R.; Ngamnithiporn, A.; Klatte, M.; Lapointe, G.; Pototschnig, G. M.; McDermott, M. S. J.; Conklin, D.; Gilmore, C. D.; Tadross, P. M.; Haley, C. K.; Glibstrup, E.; Grünanger, C. U.; Allan, K. M.; Virgil, S. C.; Slamon, D. J.; Stoltz, B. M. Concise total syntheses of (-)-jorunnamycin A and (-)-jorumycin enabled by asymmetric catalysis. Science 2019, 363, 270-275.

(17) Ladenburg, A. Synthese der activen Coniine Ber. Dtsch. Chem. Ges. 1886, 19, 2578-2583.

(18) Koltunov, K. Y.; Prakash, G. K. S.; Rasul, R.; Olah, G. A. Reactions of 5-, 6-, 7-, 8-Hydroxyquinolines and 5-Hydroxyisoquinoline with Benzene and Cyclohexane in Superacids. J. Org. Chem. 2002, 67, 4330-4336.

(19) Green, S. A.; Matos, J. L. M.; Yagi, A.; Shenvi, R. A. Branch-Selective Hydroarylation: Iodoarene-Olefin Cross Coupling. J. Am. Chem. Soc. 2016, 138, 12779-12782.

(20) Rinderhagen, H.; Waske, P. A.; Mattay, J. Facile ring opening of siloxy cyclopropanes by photoinduced electron transfer. A new way to $\beta$-keto radicals. Tetrahedron 2006, 62, 6589-6593.

(21) Molander, G.; Milligan, J. A.; Phelan, J. P.; Badir, S. O. Recent Advances in Alkyl Carbon-Carbon Bond Formation by Nickel/Photoredox Cross-Coupling. Angew. Chem., Int. Ed. 2019, $58,6152-6163$.

(22) Burdge, H. E.; Oguma, T.; Kawajiri, T.; Shenvi, R. A. Concise synthesis of GB22 by endo-selective siloxycyclopropane arylation. ChemRxiv DOI: 10.26434/chemrxiv.8263415.v1

(23) Varabyeva, N.; Barysevich, M.; Aniskevich, Y.; Hurski, A. Ti(OiPr) 4 -Enabled Dual Photoredox and Nickel-Catalyzed Arylation and Alkenylation of Cyclopropanols. Org. Lett. 2021, 23, 5452-5456.

(24) Bume, D. D.; Pitts, C. D.; Lectka, T. Tandem C-C Bond Cleavage of Cyclopropanols and Oxidative Aromatization by 
Manganese(IV) Oxide in a Direct $\mathrm{C}-\mathrm{H}$ to $\mathrm{C}-\mathrm{C}$ Functionalization of Heteroaromatics. Eur. J. Org. Chem. 2016, 26-30.

(25) Aoki, S.; Fujimura, T.; Nakamura, E.; Kuwajima, I. Palladium-Catalyzed Arylation of Siloxycyclopropanes with Aryl Triflates. Carbon Chain Elongation via Catalytic Carbon-Carbon Bond Cleavage. J. Am. Chem. Soc. 1988, 110, 3296-3298.

(26) Zuo, Z.; Ahneman, D. T.; Chu, L.; Terrett, J. A.; Doyle, A. G.; MacMillan, D. W. C. Merging photoredox with nickel catalysis: Coupling of $\alpha$-carboxyl $\mathrm{sp}^{3}$-carbons with aryl halides. Science 2014, 345, 437-440.

(27) Speckmeier, E.; Fischer, T. G.; Zeitler, K. A Toolbox Approach to Construct Broadly Applicable Metal-Free Catalysts for Photoredox Chemistry: Deliberate Tuning of Redox Potentials and Importance of Halogens in Donor-Acceptor Cyanoarenes. J. Am. Chem. Soc. 2018, 140, 15353-15365.

(28) Allais, C.; Liéby-Muller, F.; Rodriguez. J.; Constantieux, T. Metal-Free Michael-Addition-Initiated Three-Component Reaction for the Regioselective Synthesis of Highly Functionalized Pyridines: Scope, Mechanistic Investigations and Applications. Eur. J. Org. Chem. 2013, 4131-4145.

(29) Lorenz, J. C.; Long, J.; Yang, Z.; Xue, S.; Xie, Y.; Shi, Y. A Novel Class of Tunable Zinc Reagents $\left(\mathrm{RXZnCH}_{2} \mathrm{Y}\right)$ for Efficient Cyclopropanation of Olefins. J. Org. Chem. 2004, 69, 327334.

(30) Lowe, J. A.; Qian, W.; Drozda, S. E.; Volkmann, R. A.; Nason, D.; Nelson, R.B.; Nolan, C.; Liston, D.; Ward, K.; Faraci, S.; Verdries, K. Structure-Activity Relationships of Potent, Selective Inhibitors of Neuronal Nitric Oxide Synthase Based on the 6Phenyl-2-aminopyridine Structure. J. Med. Chem. 2004, 47, 15751586.

(31) Hansch, C.; Leo, A. Substituent Constants for Correlation Analysis in Chemistry and Biology. Wiley-Interscience, NY, 1979.

(32) Mazdiyasni, K. S.; Schaper, B. J.; Brown, L. M. Hexafluoroisopropoxides of Aluminum and of Some Group IV Elements. Inorg. Chem. 1971, 10, 889-892.
(33) Yamamoto, H.; Futasuta, K. 'Designer Acids': Combined Acid Catalysis for Asymmetric Synthesis. Angew. Chem. Int. Ed. 2005, 44, 1924-1942.

(34) Motiwala, H. F.; Vekariya, R. H., Aubé, J. Intramolecular Friedel-Crafts Acylation Reaction Promoted by 1,1,1,3,3,3-Hexafluoro-2-propanol. Org. Lett. 2015, 17, 5484-5487.

(35) Mitsui, S.; Imaizumi, S.; Esashi, Y. Stereochemistry and Mechanism of Catalytic Hydrogenation and Hydrogenolysis. III. Catalytic Hydrogenolysis of Benzyl-type Alcohols and Their Derivatives. Bull. Chem. Soc. Jpn. 1970, 43, $2143-2152$.

(36) Benkeser, R. A.; Arnold Jr. C.; Lambert, R. F.; Thomas, O. H. Reduction of organic compounds by lithium in low molecular weight amines. III. Reduction of aromatic compounds containing functional groups. J. Am. Chem. Soc. 1955, 77, 6042-6045.

(37) Burrows, J.; Kamo, S.; Koide, K. Scalable Birch reduction with lithium and ethylenediamine in tetrahydrofuran. Science 2021, 374, 741-746.

(38) Bertz, S. H. The First General Index of Molecular Complexity. J. Am. Chem. Soc. 1981, 103, 3599-3601.

(39) Demoret, R. M.; Baker, M. A.; Ohtawa, M.; Chen, S.; Lam, C.-C.; Khom, S.; Roberto, M.; Forli, S.; Houk, K.; Shenvi, R. A. Synthetic, Mechanistic and Biological Interrogation of Ginkgo biloba Chemical Space en route to (-)-Bilobalide. J. Am. Chem. Soc. 2020, 142, 18599-18618.

TOC Graphic

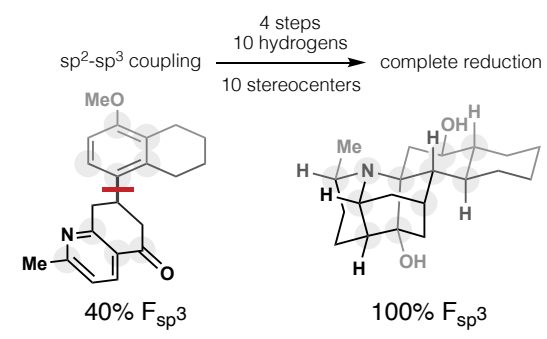

